\title{
EFFECT OF NITROGENOUS FERTILIZER RATES ON RICE YIELD, YIELD COMPONENTS AND INSECT INFESTATION OF SOME RICE CULTIVARS \\ Sultan, M.S.'; A.T.El-Kassaby' ${ }^{1}$;M.M.El-Habashy² and A. S. Taha ${ }^{2}$ \\ 1- Agronomy Department, Faculty of Agriculture, Mansoura University \\ 2- Rice Research Department, Field Crops Research Institute, Agricultural Research Center
}

\begin{abstract}
Rice is a very important cereal crop in Egypt and allover the world. In Egypt, it is an essential food crop because of shortage in wheat production, and nitrogen fertilizer is crucial to obtain a good yield. Two field experiments were conducted in 2011 and 2012 rice seasons at the Experimental Farm of Rice Research and Training Center, Sakha, kafr El-Sheikh, Egypt. The experiments aimed to evaluate yield and its components of four rice cultivars; Sakha 101, Giza 178, Egyptian Jasmine and rice Hybrid 1. These cultivars were tested under five nitrogen levels; 0, 23, 46, 69 and 92 $\mathrm{kg} \mathrm{N} / \mathrm{fed}$. in the form of urea $(46.5 \% \mathrm{~N})$. Also, the insect infestations of rice stem borer, Chilo agamemnon Bles. and rice leaf miner, Hydrellia prosternalis Deeming. were evaluated. The main results proved the superiority of Egyptian Hybrid 1 rice cultivar, concerning filled grains and yield. The second rank was that of Sakha 101 cultivar as it gave the highest values of 1000-grain weight and harvest index. According to the current data, it is recommended to use $69 \mathrm{~kg} \mathrm{~N} / \mathrm{fed}$. ( not $92 \mathrm{~kg}$ ) for fertilizing the tested cultivars, as no significant yield differences were found between the two nitrogen levels. On the other hand, it is important to avoid using overdoses of nitrogenous fertilizers because they encourage the infestation by rice stem borer and rice leaf miner.
\end{abstract}

Keywords: Rice -Nitrogenous fertilizer- Yield components- Rice cultivarsRice Leaf Miner- Rice Stem Borer.

\section{INTRODUCTION}

Rice (Oryza sativa L.) is the most important crop after wheat. It is a staple food for nearly one half of the world's population; most of them live in the developing countries. Moreover, it is a very important cereal crop in Egypt for local consumption, particularly due to shortage in wheat supply. In addition rice is an export crop, and represents an important source for foreign currency. Rice productivity is affected by several abiotic and biotic factors. Low nitrogen fertilizer is one of abiotic factors, while the insect infestations are of biotic factors. There were significant differences among rice cultivars in respect to all chemical composition and these differences are mainly due to differences in the genetic constitution (El-Hissewy et al., 2002). Nitrogen fertilization is crucial to obtain good yield, but the rates of fertilizations should be optimized. Splitting nitrogen fertilizer was proven to be an important agronomic practice that minimizes nitrogen losses and increases its efficiency ( Abd El-Wahab et al., 2005). The highest nitrogenous level ( $165 \mathrm{~kg} \mathrm{~N} / \mathrm{ha}$ ) significantly increased number of panicle /hill, panicle length, number of filled grains/ panicle, panicle weight, grain and straw yields 
and harvest index (Ebaid and Ghanem, 2001). Increasing nitrogen up to 220 $\mathrm{kg} \mathrm{N} /$ ha significantly increased number of panicles $/ \mathrm{m} 2$, grain and straw yields. Applying $165 \mathrm{~kg} \mathrm{~N} /$ ha was adequate for number of grains / panicle, grain yield, harvest index and 1000- grain weight.

Insect infestations are considered important biotic factors. Rice plants are liable to be attacked by several insect pests. In Egypt, the rice stem borer, Chilo agamemnon Bles. and the rice leaf miner Hydrellia prosternalis Deeming are the most important (Sherif, 2002). The current study aimed to investigate the effect of nitrogen fertilization rates on rice yield, yield components and insect infestations of some rice cultivars.

\section{MATERIALS AND METHODS}

Two field experiments were carried out at the Experimental Farm of Rice Research and Training Center (RRTC), Sakha, Kafr El-Sheikh, Egypt, during 2011 and 2012 rice growing seasons. The experiments aimed to evaluate yield, yield components and insect infestations of four rice cultivars ; Sakha 101, Giza 178, Egyptian Jasmine and rice Hybrid 1. These cultivars were tested under five nitrogen levels; 0, 23, 46, 69 and $92 \mathrm{~kg} \mathrm{~N} / \mathrm{fed}$. in the form of Urea $(46.5 \% \mathrm{~N})$. Also, the insect infestations of rice stem borer Chilo agamemnon Bles. and rice leaf miner, Hydrellia prosternalis, Deeming. were evaluated. The split plot design, with three replicates, was adopted, as the main plots were devoted to the four rice cultivars, while the sub-plots were assigned to the five levels of nitrogen fertilization.

The seed bed was ploughed three times, with adding calcium super phosphate $\left(15.50 \% \mathrm{P}_{2} \mathrm{O}_{5}\right)$ at the rate of $100 \mathrm{~kg} / \mathrm{fed}$. on the dry soil before ploughing. Nitrogen, in the form of urea $(46.50 \% \mathrm{~N})$, was used at a rate of $100 \mathrm{~kg} / \mathrm{fed}$. It was divided into two equal doses, the first dose was incorporated into the dry soil just before flooding. The second dose of $\mathrm{N}$ was added 15 days after sowing. Zinc sulphate $(24 \% \mathrm{Zn} \mathrm{SO}$ ), at the rate of 24 $\mathrm{kg} / \mathrm{fed}$., was added after puddling and before seeds broadcasting. The rice seeds were broadcasted at a rate of $10 \mathrm{~kg} / \mathrm{fed}$. for the Hybrid 1 cultivar, and at a rate of $40 \mathrm{~kg} / \mathrm{fed}$. for inbred varieties; Sakha 101, Giza 178, and Egyptian Jasmine on May $10^{\text {th }}$ in each season. The broadcasted seeds were previously soaked in water for 48 hours, and incubated for additional 48 hours to accelerate seed germination.

The permanental field was ploughed three times, with adding calcium super phosphate $\left(15.5 \% \mathrm{P}_{2} \mathrm{O}_{5}\right)$ at the rate of $100 \mathrm{~kg} / \mathrm{fed}$. before the third tillage. The nitrogen fertilizer was added in the form of urea $(46.5 \% \mathrm{~N})$ in three splits according to the nitrogen levels applied; $1 / 3$ as basal (incorporated into the soil before puddling), 1/3 twenty days after transplanting, and the last third was added forty days after transplanting. One month after seed sowing, the seedlings were pulled out, distributed in the permanent field, and transplanted at $20 \times 20 \mathrm{~cm}$ spacing. The split plot design with three replicates was adopted, as the main plots were devoted to the four rice cultivars, while the sub-plots were assigned to the five levels of nitrogen fertilization. The other usual field practices of rice cultivation were conducted according to the recommendations of Ministry of Agriculture. 


\section{Studied Characters;}

Plant samples were collected randomly from sub plots to estimate the following characters.

Number of panicles $/ \mathrm{m}^{2}$ :

Total number of panicles (productive tillers) in five random hills were counted, and then converted to number of panicles $/ \mathrm{m}^{2}$.

Panicle weight (g):

Average of five weighed panicles was computed, after panicle air drying.

Number of filled and unfilled grains/panicle:

Average numbers of filled and unfilled grains in five panicles were computed.

\section{0-grain weight $(g)$ :}

Samples of one thousand paddy rice grains were weighed in $\mathrm{g}$.

Grain and Straw yields (t $/ \mathrm{fed}$ ):

Plants of an area of $4 \mathrm{~m}^{2}$ (100 hills) of each experimental plot were manually harvested according to the harvest time of each treatment. The plants were tied, labeled and moved to a floor for air drying for five days. The plants were mechanically threshed, and each of rice grain and straw were separately weighed in $\mathrm{kg}$. On the basis of $14 \%$ moisture content, the weights of grain and straw were adjusted to tons per Fed.

Harvest index:

It was determined according to Yoshida (1981) by subdividing weight of grain yield (t/fed) (economic yield.) on the total dry weight (weight of grains and straw).

$$
\text { Harvest index }=\quad \frac{\text { Economical yield } \text { (grain yield) }}{\text { Biological yield (grain + straw yields) }}
$$

Insect infestation evaluation:-

Rice leaf miner, Hydrellia prosternalis Deem :-

Twenty-five days after transplanting, 100 rice leaves were picked from each plot, and the leaf miner infested leaves were counted.

\section{Rice stem borer, Chilo agamemnon Bles. :-}

Three weeks prior to harvest, white head percentages, were estimated. White heads are the empty rice panicles (unfilled grains) due to tunneling of borer larvae in the base of panicles, preventing the nutrients to go up. Each plot was represented by five hills, cut at the soil surface. Total number of tillers was recorded, and tillers having white heads were calculated, thus, the percentages of white heads were calculated.

Statistical analysis:-

Data were subjected to the standard statistical analysis by MSTATC. Means were compared using Duncan's Multiple Range Test (1955).

\section{RESULTS AND DISCUSION}

Results in Table 1 indicated that rice cultivars significantly varied in number of panicles $/ \mathrm{m}^{2}$ in both seasons. Hybrid 1 cultivar recorded the highest number of panicles $/ \mathrm{m}^{2}$ (615.13 and 572.0) followed by Giza 178 (613.2 and 
$540.7)$ in the first and second seasons, respectively. The lowest numbers of panicles $/ \mathrm{m}^{2}$ (455.9 and 453.0) were produced by Egyptian Jasmine cultivar in both seasons. Similar results were obtained by El-Kassaby et al. (2012).

Panicles of Egyptian Jasmine (Table 1) were the heaviest ones; 4.24 and $4.79 \mathrm{~g} /$ panicle, followed by those of Hybrid 1, and Sakha 101 cultivar, while the panicles of Giza 178 were the lightest ones; 3.27 and $3.86 \mathrm{~g} /$ panicle in 2011 and 2012 rice seasons, respectively. The results indicated that most cultivars had a significant effect on panicle weight in both seasons. Highly significant differences were computed among the evaluated cultivars concerning this trait. There were significant differences among cultivars in respect to all chemical composition and these differences were mainly due to differences in the genetic constitution of these cultivars (El-Hissewy et al., 2002).

Table (1): Yield components of some rice cultivars as affected by different levels of nitrogen fertilization during 2011 and 2012 seasons.

\begin{tabular}{|c|c|c|c|c|c|c|c|c|}
\hline \multirow[t]{2}{*}{ Treatment } & \multicolumn{2}{|c|}{$\begin{array}{c}\text { No. of } \\
\text { Panicles } / \mathrm{m}^{2}\end{array}$} & \multicolumn{2}{|c|}{$\begin{array}{l}\text { Panicle weight } \\
\text { (g) }\end{array}$} & \multicolumn{2}{|c|}{$\begin{array}{c}\text { No. of filled } \\
\text { grains/panicle }\end{array}$} & \multicolumn{2}{|c|}{$\begin{array}{l}\text { No. of unfilled } \\
\text { grains/panicle }\end{array}$} \\
\hline & 2011 & 2012 & 2011 & 2012 & 2011 & 2012 & 2011 & 2012 \\
\hline \multicolumn{9}{|l|}{ Cultivar } \\
\hline Sakha 101 & $533.4 \mathrm{ab}$ & $529.3 \mathrm{ab}$ & $4.13 a$ & $3.95 b$ & $135.90 \mathrm{~b}$ & $142.83 \mathrm{~b}$ & $18.90 \mathrm{~b}$ & $13.93 \mathrm{~b}$ \\
\hline Giza 178 & $613.2 \mathrm{a}$ & $540.7 \mathrm{a}$ & $3.27 \mathrm{~b}$ & $3.86 \mathrm{~b}$ & $139.10 \mathrm{~b}$ & $157.40 \mathrm{a}$ & $17.94 \mathrm{~b}$ & $10.13 c$ \\
\hline E. Jasmine & $455.9 \mathrm{~b}$ & $453.0 \mathrm{~b}$ & $4.24 \mathrm{a}$ & $4.79 \mathrm{a}$ & $128.40 \mathrm{c}$ & $139.60 \mathrm{~b}$ & $32.07 \mathrm{a}$ & $17.46 \mathrm{a}$ \\
\hline Hybrid 1 & $615.13 \mathrm{a}$ & $572.0 \mathrm{a}$ & $4.17 \mathrm{a}$ & $3.94 \mathrm{~b}$ & $158.10 \mathrm{a}$ & $159.13 \mathrm{a}$ & $7.97 \mathrm{c}$ & $8.77 \mathrm{c}$ \\
\hline F test & * & * & $\star \star$ & * & $\star \star$ & $\star \star$ & $\star \star$ & $\star *$ \\
\hline \multicolumn{9}{|l|}{ N. level (kg/fed) } \\
\hline Zero & $409.7 c$ & $395.0 \mathrm{c}$ & $3.31 \mathrm{c}$ & $3.72 \mathrm{c}$ & $128.70 \mathrm{c}$ & $136.10 \mathrm{c}$ & $14.95 \mathrm{c}$ & $9.85 \mathrm{e}$ \\
\hline 23 & $514.0 \mathrm{~b}$ & $457.0 \mathrm{c}$ & $3.95 \mathrm{ab}$ & 3.84 bc & $137.30 \mathrm{~b}$ & $145.85 \mathrm{~b}$ & $16.47 \mathrm{bc}$ & $11.15 \mathrm{~d}$ \\
\hline 46 & $541.4 \mathrm{~b}$ & $535.0 \mathrm{~b}$ & $3.92 \mathrm{ab}$ & $4.21 \mathrm{ab}$ & $144.22 \mathrm{ab}$ & $157.54 \mathrm{ab}$ & $18.92 \mathrm{~b}$ & $12.50 \mathrm{c}$ \\
\hline 69 & $636.9 \mathrm{a}$ & $587.5 \mathrm{ab}$ & $4.19 \mathrm{a}$ & $4.36 \mathrm{a}$ & $149.45 \mathrm{a}$ & $165.65 \mathrm{a}$ & $19.97 \mathrm{~b}$ & $13.27 \mathrm{~b}$ \\
\hline 92 & $669.9 \mathrm{a}$ & $644.2 \mathrm{a}$ & $4.20 \mathrm{a}$ & $4.44 \mathrm{a}$ & $148.40 \mathrm{a}$ & $166.75 \mathrm{a}$ & $25.85 \mathrm{a}$ & $15.95 \mathrm{a}$ \\
\hline $\mathrm{F}$ test & $\star \star$ & $\star \star$ & ** & ** & ** & $\star \star$ & ** & $\star \star$ \\
\hline $\begin{array}{c}\text { Interaction - } \\
\text { F test }\end{array}$ & NS & NS & NS & NS & NS & NS & NS & NS \\
\hline
\end{tabular}

*, ** and NS indicate $P<0.05, P<0.01$ and not significant, respectively

In the same column, means followed by the same letter are not significantly different at $5 \%$ level of probability according to DMRT.

Number of filled and unfilled grains varied with highly significant differences among the four considered rice cultivars in both seasons.

Panicles of Hybrid 1 contained the greatest number of filled grains (158.10 and 159.13 grains/panicle) in the first and second seasons, respectively. In contrast, panicles of Egyptian Jasmine contained the lowest values of filled grains; 128.40 and 139.60 grains/ panicle in 2011 and 2012 rice seasons, respectively.

In the reverse trend, the lowest numbers of unfilled grains (7.97 and 8.77 grains/ panicle) were recorded in Hybrid 1 cultivar in the first and second seasons, respectively. The greatest values of unfilled grains (32.07 and 17.46 grains/ panicle) were recorded with Egyptian Jasmine in 2011 and 2012 
seasons, respectively. Similar results were obtained by Abou Khalifa et al. (2007).

Data presented in Table (1) show that the variation in nitrogenous fertilization levels induced highly significant differences in number of panicles $/ \mathrm{m}^{2}$, and panicle weight in both seasons.

The highest number of panicles $/ \mathrm{m}^{2}$ (699.9 and 644.2) were recorded with the treatment of $92 \mathrm{~kg} \mathrm{~N} / \mathrm{fed}$, followed by those at $69 \mathrm{~kg} \mathrm{~N} / \mathrm{fed}(636.9$ and 587.5 panicles $/ \mathrm{m}^{2}$ ) in the first and second seasons, respectively. The lowest numbers of panicles were found in the non-fertilized plots (409.7 and 395.0 panicles $/ \mathrm{m}^{2}$ ).

The heaviest panicles ( 4.20 and $4.44 \mathrm{~g} /$ panicle) were found in rice plots fertilized with $92 \mathrm{~kg} \mathrm{~N} / \mathrm{fed}$, followed by those in plots fertilized with $69 \mathrm{~kg} \mathrm{~N} / \mathrm{fed}$ (4.19 and $4.36 \mathrm{~g} /$ panicle) in 2011 and 2012 seasons, respectively. The lightest panicles (3.31 and $3.72 \mathrm{~g} /$ panicle) were recorded in the non-fertilized plots. The increase in panicle weight may be attributed to the increase in number of grains/panicle which increased with increasing rates of nitrogen fertilization. Ebaid and Ghanem (2001) reported that the nitrogenous level at $165 \mathrm{~kg} / \mathrm{ha}$ surpassed 55 and $110 \mathrm{~kg} \mathrm{~N} / \mathrm{ha}$ in number of panicles $/ \mathrm{m}^{2}$ and panicle weight.

Both number of filled and unfilled grains/panicle varied with highly significant differences due to different levels of nitrogen fertilization (Table 1). The highest number of filled grains were obtained with 69 and $92 \mathrm{~kg} \mathrm{~N} / \mathrm{fed}$, without significant differences between the two nitrogenous levels. On the other hand, the lowest numbers of filled grains were detected in non-fertilized plots (128.70 and 136.10) in the first and second seasons, respectively.

The number of unfilled grains was highest at $92 \mathrm{~kg} \mathrm{~N} / \mathrm{fed}(25.85$ and 15.95 grains/panicle) in the first and second seasons, respectively, followed by those at $69 \mathrm{~kg} \mathrm{~N} / \mathrm{fed}$; (19.97 and 13.27 grains/panicle). Similar findings were reported by Chakraborty (2011).

The results in Table 2 indicated that the heaviest 1000-grain weight was obtained with Egyptian Jasmine ( 27.22 and $26.30 \mathrm{~g}$ ) and Sakha 101 ( 27.03 and $28.01 \mathrm{~g}$ ) in the first and second seasons, respectively. Giza 178 cultivar had the least 1000-grain weight with values of 23.35 and $22.42 \mathrm{~g}$ in the 2011 and 2012 seasons, respectively. Statistical analysis showed that the differences among rice cultivars concerning 1000- grain weight were highly significant. The current results are in accordance with those reported ElKady and Abd El-Wahab (1999).

Rice cultivars displayed highly significant and significant differences in their grain yield Table 2 in both seasons. Hybrid 1 and Sakha 101 produced the highest grain yield, followed by Giza 178 cultivar, and then Egyptian Jasmine that produced the lowest grain yield (3.71 and $3.78 \mathrm{t} / \mathrm{fed}$. in the first and second seasons, respectively). These results are in accordance with those reported Abou Khalifa et al. (2007) and El-Kassaby et al. (2012). The highest straw yield was obtained with Egyptian Jasmine, followed by that of Hybrid 1, while straw yields of Sakha 101 and Giza 178 were lower. Highly significant differences in straw yield were found among rice cultivars in 2011 season, but the differences were significant in 2012 season (Table 2). 
Table 2: 1000-grain weight, Grain and straw yield, and harvest index of some rice cultivars as affected by different levels of nitrogenous fertilization in both seasons.

\begin{tabular}{|c|c|c|c|c|c|c|c|c|}
\hline \multirow[t]{2}{*}{ Treatment } & \multicolumn{2}{|c|}{$\begin{array}{c}\text { 1000-grain weight } \\
(\mathrm{g})\end{array}$} & \multicolumn{2}{|c|}{ Grain yield (t/fed) } & \multicolumn{2}{|c|}{ Straw yield ( $t / f e d)$} & \multicolumn{2}{|c|}{ Harvest index } \\
\hline & 2011 & 2012 & 2011 & 2012 & 2011 & 2012 & 2011 & 2012 \\
\hline \multicolumn{9}{|l|}{ Cultivar } \\
\hline Sakha 101 & $27.03 \mathrm{a}$ & $28.01 \mathrm{a}$ & $4.05 \mathrm{ab}$ & $4.43 \mathrm{ab}$ & $4.80 \mathrm{~b}$ & $5.58 \mathrm{ab}$ & $45.85 \mathrm{a}$ & 43.95 \\
\hline Giza 178 & $23.35 \mathrm{~b}$ & $22.42 \mathrm{~d}$ & $3.98 \mathrm{bc}$ & $3.98 \mathrm{bc}$ & $4.96 \mathrm{~b}$ & $5.39 \mathrm{~b}$ & $42.52 \mathrm{~b}$ & 41.75 \\
\hline E. Jasmine & $27.22 \mathrm{a}$ & $26.30 \mathrm{~b}$ & $3.71 \mathrm{c}$ & $3.78 \mathrm{c}$ & $5.87 \mathrm{a}$ & $6.12 \mathrm{a}$ & $37.18 \mathrm{c}$ & 40.17 \\
\hline Hybrid 1 & $25.37 \mathrm{ab}$ & $24.65 \mathrm{c}$ & $4.38 \mathrm{a}$ & $4.53 \mathrm{a}$ & $5.27 b$ & $6.04 \mathrm{a}$ & $45.32 \mathrm{a}$ & 43.03 \\
\hline $\mathrm{F}$ test & $\star \star$ & $\star \star$ & $\star \star$ & $*$ & $\star \star$ & * & ** & NS \\
\hline \multicolumn{9}{|l|}{ N. level (kg/fed) } \\
\hline Zero & $23.20 \mathrm{c}$ & $23.62 \mathrm{c}$ & $3.21 \mathrm{~d}$ & $3.13 \mathrm{c}$ & $4.42 \mathrm{~d}$ & $4.60 \mathrm{~d}$ & $39.10 \mathrm{~d}$ & $40.50 \mathrm{bc}$ \\
\hline 23 & $24.50 \mathrm{bc}$ & $24.33 \mathrm{~b}$ & $3.63 \mathrm{c}$ & $3.92 \mathrm{~b}$ & $4.67 \mathrm{~cd}$ & $5.23 \mathrm{~cd}$ & $42.78 \mathrm{bc}$ & $42.99 \mathrm{a}-\mathrm{c}$ \\
\hline 46 & $25.16 \mathrm{ab}$ & $25.43 \mathrm{ab}$ & $4.04 \mathrm{~b}$ & $4.54 \mathrm{a}$ & $5.00 \mathrm{c}$ & $5.73 \mathrm{bc}$ & $44.78 \mathrm{ab}$ & $44.20 \mathrm{ab}$ \\
\hline 69 & $26.26 \mathrm{a}$ & $26.54 \mathrm{a}$ & $4.81 \mathrm{a}$ & $4.73 \mathrm{a}$ & $5.68 \mathrm{~b}$ & $6.04 \mathrm{~b}$ & $45.93 \mathrm{a}$ & $44.50 \mathrm{a}$ \\
\hline 92 & $25.14 \mathrm{ab}$ & $25.75 \mathrm{ab}$ & $4.59 \mathrm{a}$ & $4.71 \mathrm{a}$ & $6.39 \mathrm{a}$ & $7.29 \mathrm{a}$ & $41.98 \mathrm{c}$ & $39.33 \mathrm{c}$ \\
\hline $\mathrm{F}$ test & $\star \star$ & $\star \star *$ & $\star \star \star$ & ** & ** & $\star \star *$ & * & * \\
\hline $\begin{array}{c}\text { Interaction - } \\
\text { F test }\end{array}$ & NS & NS & NS & NS & NS & NS & NS & NS \\
\hline
\end{tabular}

*, ** and NS indicate $P<0.05, P<0.01$ and not significant, respectively

In the same column, means followed by the same letter are not significantly different at $5 \%$ level of probability according to DMRT.

The greatest harvest index was that of Sakha 101 and Hybrid 1, while the least one was that of Egyptian Jasmine. The differences in the harvest index were highly significant in the first season, but insignificant in the second one.

The highest values of 1000-grain weight (Table 2) were recorded in rice plots fertilized with $69 \mathrm{~kg} \mathrm{~N} / \mathrm{fed}$ (26.26 and 26.54 in the first and second seasons, respectively). The lowest values were recorded in non-fertilized rice plants. Highly significant differences were recorded in 1000-grain weight, due to different levels of nitrogenous fertilization. The increase in 1000-grain weight with increasing nitrogen level may be due to the accumulation of more assimilates and vigor growth of rice plants. Similar results were obtained by Gorgy et al. (2011).

Data in (Table 2) show that the higher grain yields were obtained, in both seasons, at $69 \mathrm{~kg} \mathrm{~N} / \mathrm{fed}$, with values of 4.81 and $4.73 \mathrm{t} / \mathrm{fed}$, respectively, followed by rice grain yield at $92 \mathrm{~kg} \mathrm{~N} / \mathrm{fed}$. with no significant differences between both $\mathrm{N}$ levels. The least grain yield was obtained in the non-fertilized plots ; 3.21 and 3.13 preceded by those fertilized with $23 \mathrm{~kg} \mathrm{~N} / \mathrm{fed} ; 3.63$ and $3.92 \mathrm{t} / \mathrm{fed}$, in the first and second seasons, respectively.

The straw yield was highest at $92 \mathrm{~kg} \mathrm{~N} / \mathrm{fed}$, followed by that at $69 \mathrm{~kg} \mathrm{~N} / \mathrm{fed}$, in both seasons.

The harvest index was superior at $69 \mathrm{~kg} \mathrm{~N} / \mathrm{fed} ; 45.93$ and 44.5, followed by that at $46 \mathrm{~kg} \mathrm{~N} / \mathrm{fed} ; 44.78$ and 44.20 , but lowest in the non-fertilized (control) plots; 39.10 and 40.50, in 2011 and 2012 seasons, respectively. From the abovementioned results, it could be concluded that there is no need for raising nitrogen fertilization over $69 \mathrm{~kg} / \mathrm{fed}$. 
The highest grain and straw yields of Hybrid 1 could be attributed mainly to its higher tillering ability, large leaf area and higher dry matter production. Similar results were found by Talathi et al. (2009).

\section{Insect Infestation:-}

\section{Rice leaf miner Hydrellia prosternalis Deem. :-}

Percentage of infested leaves:-

Data presented in Table 3 show percentages of rice leaves infested with the rice leaf miner, Hydrellia prosternalis as affected by rice cultivars and nitrogenous fertilization levels. In 2011 season, the differences in infestation of rice cultivars were highly significant. Giza 178 recorded the highest infestation (32.60 \%), followed by Egyptian Jasmine (27.93\%), while Sakha 101 was the least infested one $(15.40 \%)$. Similar results were obtained in 2012 rice season, but the differences were not significant. However, Egyptian Jasmine was the highest infested (77.33\%), and Giza 178 occupied the second rank (73.47\%). The least infested cultivar was Sakha 101 with $68.00 \%$ infested leaves. miner in both seasons. In contrast, Karuppuchamy and Uthamasamy (1984) reported that nitrogen fertilizer had no effect on the leaf miner damage.

Table 3: Percentage of rice leaves infested with rice leaf miner of some rice cultivars under different nitrogen levels in both seasons

\begin{tabular}{|c|c|c|}
\hline Treatment & $\mathbf{2 0 1 1}$ & $\mathbf{2 0 1 2}$ \\
\hline Cultivar & & 68.00 \\
\hline Sakha 101 & $15.40 \mathrm{~b}$ & 73.47 \\
\hline Giza 178 & $32.60 \mathrm{a}$ & 77.33 \\
\hline Egyptian Jasmine & $27.93 \mathrm{a}$ & 68.73 \\
\hline Hybrid 1 & $26.27 \mathrm{a}$ & $\mathrm{NS}$ \\
\hline F test & ${ }^{\star *}$ & $60.25 \mathrm{c}$ \\
\hline Nitrogen level (kg/fed) & & $70.00 \mathrm{bc}$ \\
\hline Control (zero) & $19.33 \mathrm{~b}$ & $74.00 \mathrm{ab}$ \\
\hline $23(\mathrm{~kg} \mathrm{~N} / \mathrm{fed})$ & $26.75 \mathrm{a}$ & $72.42 \mathrm{ab}$ \\
\hline $46(\mathrm{~kg} \mathrm{~N} / \mathrm{fed})$ & $25.00 \mathrm{ab}$ & $82.75 \mathrm{a}$ \\
\hline $69(\mathrm{~kg} \mathrm{~N} / \mathrm{fed})$ & $25.92 \mathrm{ab}$ & $\mathrm{NS}$ \\
\hline $92(\mathrm{~kg} \mathrm{~N} / \mathrm{fed})$ & $30.75 \mathrm{a}$ & \\
\hline F test & ** & $\mathrm{NS}$ \\
\hline Interaction - F test & & \\
\hline
\end{tabular}

${ }^{*},{ }^{* *}$ and NS indicate $\mathrm{P}<0.05, \mathrm{P}<0.01$ and not significant, respectively.

In the same column, means followed by the same letter are not significantly different at $5 \%$ level of probability according to DMRT.

Sakha 101 and Giza 178 rice cultivars were classified as moderately resistant to the rice leaf miner Rice Research and Training Center (2008).

Rice stem borer, Chilo agamemnon Bles. :-

White heads:-

Data in (Table 4) show the rice stem borer infestation, expressed as white heads, as affected by rice cultivars, as well as by nitrogenous levels.

In 2011 season, the infestation of cultivars by the borer varied with highly significant differences, with Egyptian Jasmine being the higher infested 
cultivar (3.00\% white head), followed by Giza 178 (2.59 \%). In 2012 season, the cultivars varied in white head symptoms with significant differences. Giza 178 and Egyptian Jasmine were more infested $(5.12$ and $4.76 \%$, respectively) than Hybrid 1 (3.65\%), while Sakha 101 was the least infested cultivar (1.35\% white heads). Nitrogenous fertilization levels resulted in highly significant differences in white head values in both seasons. The highest infestations; 3.71 and $6.28 \%$ were recorded with $92 \mathrm{~kg} \mathrm{~N} / \mathrm{fed}$ in 2011 and 2012 seasons, respectively. The second rank was that at $69 \mathrm{~kg} \mathrm{~N} / \mathrm{fed}(2.03$ and $4.64 \%$ in the first and second seasons, respectively). The least infestations were detected in the non-fertilized plots (0.79 and $1.66 \%)$, or in plots fertilized with $23 \mathrm{~kg} \mathrm{~N} / \mathrm{fed}$ ( $1.07 \& 2.67 \%$ white heads).

Table 4: White head percentage, caused by rice stem borer, of some rice cultivars, as affected by nitrogenous fertilizer during 2011 and 2012 seasons.

\begin{tabular}{|c|c|c|}
\hline Treatment & 2011 & 2012 \\
\hline \multicolumn{3}{|l|}{ Cultivar } \\
\hline Sakha 101 & $0.47 \mathrm{~b}$ & $1.35 \mathrm{~b}$ \\
\hline Giza 178 & $2.59 \mathrm{a}$ & $5.12 \mathrm{a}$ \\
\hline Egyptian Jasmine & $3.00 \mathrm{a}$ & $4.76 \mathrm{ab}$ \\
\hline Hybrid 1 & $1.25 \mathrm{~b}$ & $3.65 a b$ \\
\hline $\mathrm{F}$ test & $\star *$ & * \\
\hline \multicolumn{3}{|l|}{ Nitrogen level (kg/fed) } \\
\hline Control (zero) & $0.79 \mathrm{~b}$ & $1.66 \mathrm{~b}$ \\
\hline $23(\mathrm{~kg} \mathrm{~N} / \mathrm{fed})$ & $1.07 \mathrm{~b}$ & $2.67 \mathrm{~b}$ \\
\hline $46(\mathrm{~kg} \mathrm{~N} / \mathrm{fed})$ & $1.88 \mathrm{ab}$ & $3.34 a b$ \\
\hline $69(\mathrm{~kg} \mathrm{~N} / \mathrm{fed})$ & $2.03 \mathrm{ab}$ & $4.64 \mathrm{ab}$ \\
\hline $92(\mathrm{~kg} \mathrm{~N} / \mathrm{fed})$ & $3.71 \mathrm{a}$ & $6.28 \mathrm{a}$ \\
\hline $\mathrm{F}$ test & $\star *$ & ** \\
\hline Interaction - $\mathrm{F}$ test & NS & NS \\
\hline
\end{tabular}

${ }^{*},{ }^{* \star}$ and $\mathrm{NS}$ indicate $\mathrm{P}<0.05, \mathrm{P}<0.01$ and not significant, respectively.

In the same column, means followed by the same letter are not significantly different at $5 \%$ level of probability according to DMRT.

It was found that the indica rice types, Egyptian Jasmine and Hybrid 1 had higher borer infestation than the japonica rice types, Sakha 101. Sherif (1996) indicated that the borer infestation to rice cultivars was higher with indica or indica $\times$ japonica rices than with pure japonica rices. The response of rice plants to infestation by the rice stem borer was similar to the results obtained by Badr and EL-Habashy (2007) who obtained the higher insect infestation at the high nitrogen levels; 80 and $60 \mathrm{~kg} \mathrm{~N} / \mathrm{fed}$.

$\mathrm{Lu}$, et al (2007) explained the effect of higher nitrogenous doses in raising rice stem borer infestation, by the increase in the succulence of stems and leaves. This can lead to a greater stem borer attack, higher larval weight, meanwhile shorter development duration of the rice stem borer. Thus, the rice stem borer feeding upon plants highly fertilized with nitrogen can build up greater populations, which reflects more damage to rice plants. Accordingly, wise application of mineral nitrogen doses (as recommend) should be strictly followed to avoid rice stem borer outbreak. 


\section{REFERENCES}

Abd El-Wahab, A.E.; S. A. Ghanem; A. T. Badawi; F. N. Mahrous and A. A. Abd EL-Rahman (2005). Improved rice cultural practices in Egypt. Egypt. J. Agric. Res., 83 (5A): 61- 78.

Abou Khalifa, A.A.; A.E. Abd El Wahab; A. M. EL Ekhtyar and B. A. Zaed (2007). Response of some hybrid rice varieties to irrigation intervals under different dates of sowing. African crop sci. Conf. Proc. Vol. 8: 6774.

Badr, E.A.S. and M.M. El- Habashy (2007). Influence of mineral nitrogen and farmyard manure fertilizers on some rice diseases and insects. J. Agric. Sci., Mansoura Univ., 32(5): 3465 -3475.

Chakraborty, K. (2011). Influence of inorganic fertilizer on plant characters, yield generation and the incidence of yellow stem borer Scirpophaga incertulas Walker in the field of local scented paddy cultivar Tulaipanji. Inter. J. of Appl. Bio. and Pharmaceutical Technol. 2(4): 264- 273.

Duncan, D. B. (1955). Multiple range and multiple F.test. Biometrics. 11: 142.

Ebaid, R. A. and S. A. Ghanem, (2001). Effect of nitrogenous and potash fertilizers on the productivity of Sakha 101 rice cultivar. J. Agric. Sci., Mansoura Univ., 26(4):1833-1840.

El-Hissewy, A. A.; L. F. Rizk; S. N. A. El- Rahman (2002). A study on the effect of strong period and storage bag son the chemical composition of rice grains of some Egyptian rice varieties. Egypt. J. of Agric. Res. 80(4), 1645-1654.

El-Kady, A. A. and A. E. Abd El-Wahab (1999). Nitrogen fertilizer management and its effect on growth, yield and grain quality of some Egyptian rice cultivars. Egypt J. Appl. Sci., 14(7): 26-35.

El-Kassaby, A. T.; M. H. Ghonima; A. A. Abd-Allah and T. M. El-Hefnawy (2012). Effect of seedling age and plant spacing on growth characters and yield of some rice cultivars. J. of Plant Production, Mansoura Univ., 3(4): 705-714.

Gorgy, R. N.; I. S. El- Refaee and M. M. Nasser (2011). Influence of seedling age and nitrogen fertilizer levels on growth, grain yield, $\mathrm{N}$ - uptake and $\mathrm{N}$ - use efficiency of hybrid rice varieties. J. of Plant Production, Mansoura Univ., 2(1): 67-80.

Karuppuchamy, P. and S. Uthamasamy (1984). Influence of flooding, fertilizer, and plant spacing on insect pest incidence. Inter. Rice Res. Newsletter, 9(6): 17-25.

LU, Z.X.; K.L. Heong; X. P. Yu and C. Hu (2007). Effects of nitrogen fertilizers on herbivores and its stimulation to major insect pests in rice. Rice Sci., 14(1): $56-66$.

Rice Research and Training Center (2008). Technical recommendation for Rice Research and Training Center, Agric. Res. Center, Ministry of Agric. and land Reclamation.

Sherif, M. R. (1996). Yield losses in the Egyptian rice fields occurred by rice stem borer in relation to cultivar acreage and light trap catches. J. Agric. Sci. Mansoura Univ., 21(12): 4537-4545. 
Sherif, M. R. (2002). Rice insect pests. In Rice in Egypt, Pp. 248-286. (ed. T. Castillo ). Rice Research and Training Center, Agric. Res. Center, Egypt.

Talathi, M. S.; S. S. Pinjari ; N. J. Ranshur ; T. S. Bhondave and J. S. Suryawanshi (2009). Productivity and economics of rice groundnut cropping system under integrated nutrient management. Inter. J. of Agric. Sci.,5(2): 472-476.

Yoshida, S. (1981). Fundamentals of Rice Crop Science. IRRI, Los Banos, Laguna, Philippines, pp. 61-226.

تأثثير معدلات السماد النيتروجينس علي المحصول ومكوناتها والإصـابات الحشرية لبعض أصناف الأرز

'محمود سليمان سلطان' ، عوض طافه القصبي'، محمود محمد الحبثي' و أحمد سمير طه'

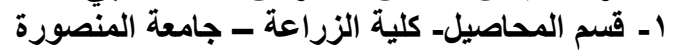

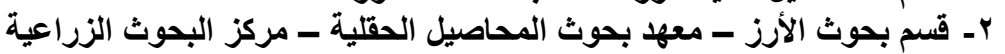

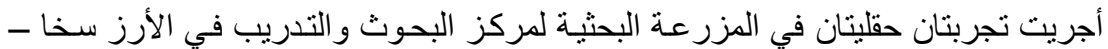

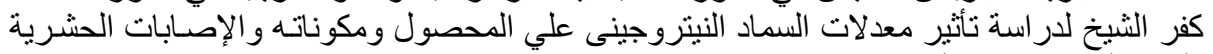

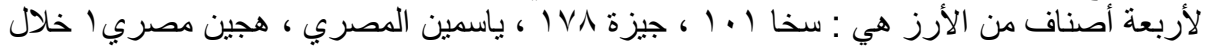

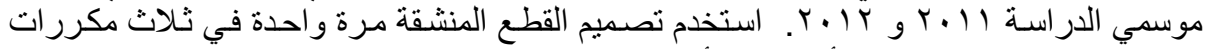

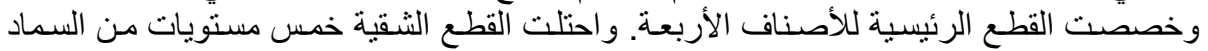

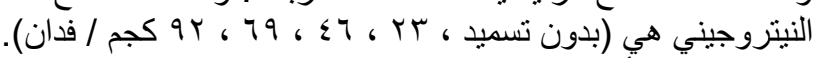

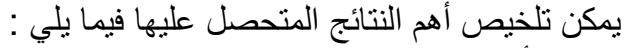

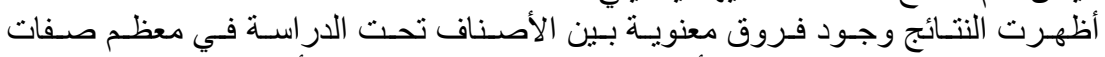

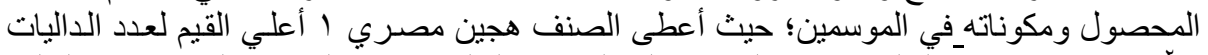

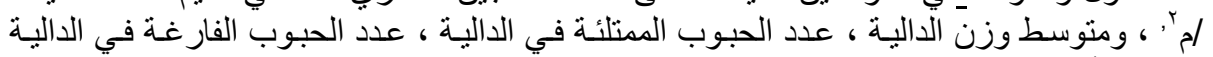

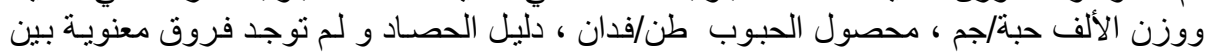

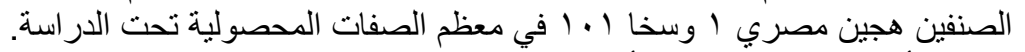

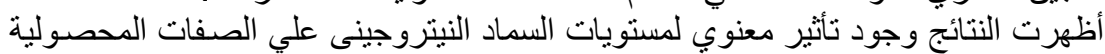

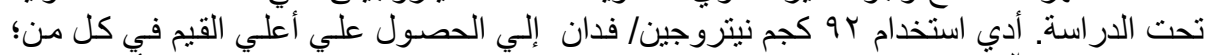

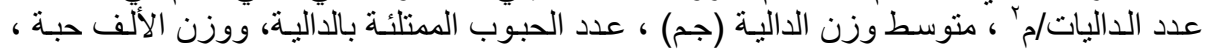

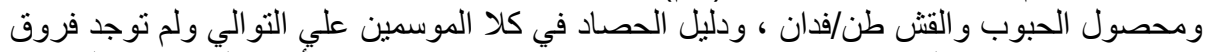

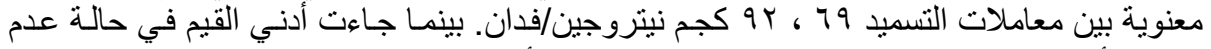

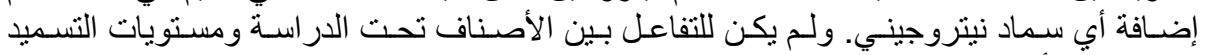
النيتروجيني أثر معنوي علي الصفات المحصولية تحت المتين الدراسة في كلا الموسمين.

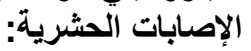

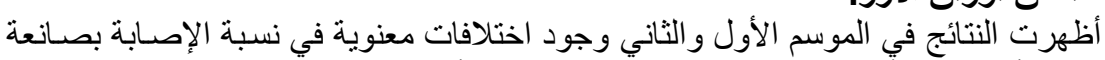

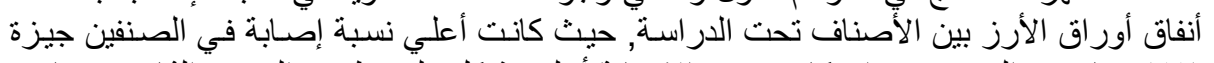

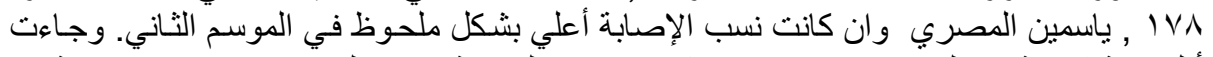

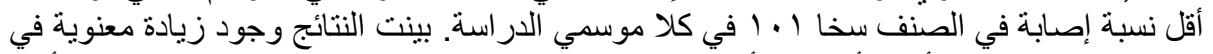

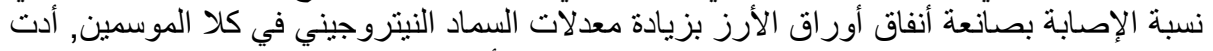
إضافة النيتروجين بمعدل بو كجم/فدان إلي الحصول علي أعلي نسانة الإنة إصابة في كلا الموسمين. 


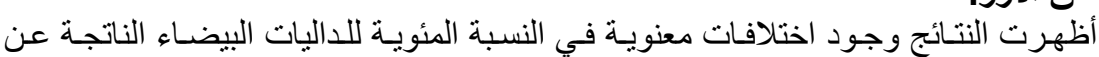

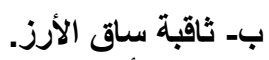

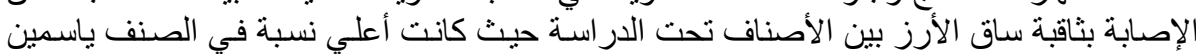

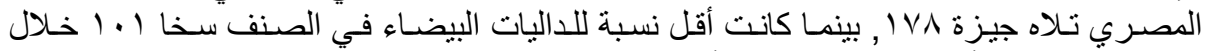

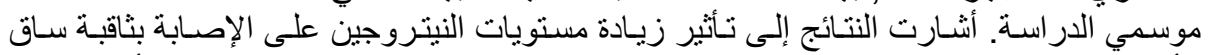

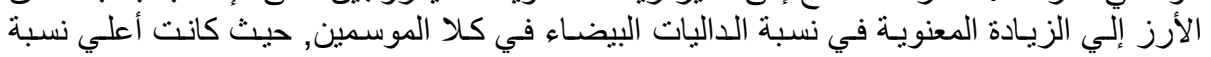

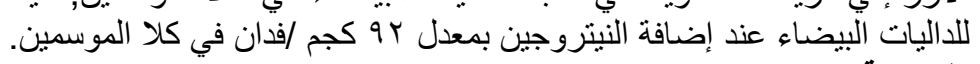

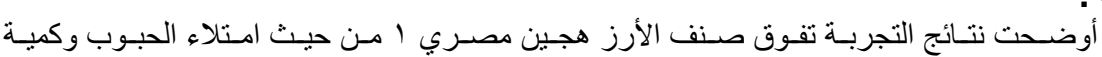

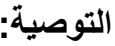

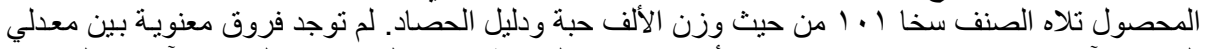

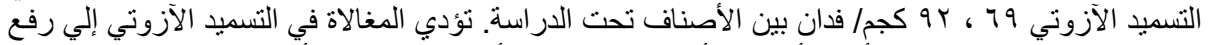

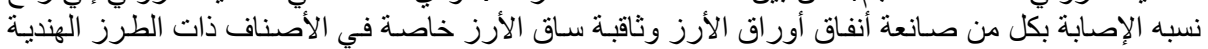
و الأصناف ذات الطرز الهندية اليابانية.

كلية الزراعة - جامعة المنصورة

قام بتحكيم البحث

مركز البحوث الزراعيه

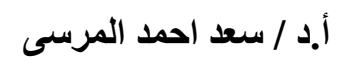

أ.د / محمود رمزى شريف 